This item was submitted to Loughborough's Research Repository by the author.

Items in Figshare are protected by copyright, with all rights reserved, unless otherwise indicated.

\title{
The violations of empathy
}

\section{PLEASE CITE THE PUBLISHED VERSION}

http://dx.doi.org/10.3898/NEWF:89/90.09.2016

\section{PUBLISHER}

Lawrence and Wishart $@$ The Author

\section{VERSION}

AM (Accepted Manuscript)

\section{PUBLISHER STATEMENT}

This work is made available according to the conditions of the Creative Commons Attribution-NonCommercialNoDerivatives 4.0 International (CC BY-NC-ND 4.0) licence. Full details of this licence are available at: https://creativecommons.org/licenses/by-nc-nd/4.0/

\section{LICENCE}

CC BY-NC-ND 4.0

\section{REPOSITORY RECORD}

Cooke, Jennifer. 2016. "The Violations of Empathy”. figshare. https://hdl.handle.net/2134/24268. 


\section{The Violations of Empathy}

\section{Jennifer Cooke}

Empathy is a young word: it first arrived in English in 1909 as a translation of the German term Einfühlung, 'feeling into', in a text by the American psychologist Edward Titchener. ${ }^{1}$ Einfühlung itself was a technical neologism, coined earlier by Robert Vischer in his 1873 discussion of the psychological dimension of aesthetics, and then expanded upon by the psychologist Theodor Lipps. ${ }^{2}$ It is to this German tradition and its Anglophone proponents that Vernon Lee refers when she makes empathy the crucial component of her psychological aesthetics in her co-authored book of 1912, Beauty and Ugliness and Other Studies in Psychological Aesthetics. ${ }^{3}$ From these specialised and technical beginnings in a branch of German-inflected thinking that combined ideas from psychology and aesthetics to discover how we relate to artworks, empathy has since migrated to name interpersonal states and affects which align closely with non-aesthetic terms, especially its more ancient cousin, sympathy, the rather later psychoanalytic concept, identification, and more recent theories from psychology such as Theory of Mind. In what follows, I examine literary and critical theory accounts of empathy and read two poems to question the usual assumption that empathy is benign. Rob Halpern's Common Place has a surprising alignment with Lee's earlier aesthetic theory of empathy

\footnotetext{
I would like to thank the two anonymous reviewers of this article and Jill Richards for their illuminating comments upon the first draft.

${ }^{1}$ Edward Bradford Titchener, Lectures on the Experimental Psychology of Thought-Processes. New York: The Macmillan Company, 1909, p. 21.

${ }^{2}$ A useful overview of Lee's thought and its influences is provided in Carolyn Burdett, "'The subjective insider us can turn into the object outside": Vernon Lee's Psychological Aesthetics', 19: Interdisciplinary Studies in the Long Nineteenth Century 12 (2011), pp. 1-31.

3 Vernon Lee and C. Anstruther-Thomson, Beauty and Ugliness and Other Studies in Psychological Aesthetics. London: John Lane Company, 1912.
} 
but rejects the later sense of the term, and in so doing creates a disturbing, and, I argue, violating, sexual fantasy out of a corpse. Andrea Brady's 'Song for Florida 2' explores a different way in which empathy violates by colonising the emotions of the other and erasing the specificity-and, indeed, masking the injustice-of their experience. Halpern's Common Place and Brady's 'Song for Florida 2' respond to the suicide of a Guantánamo detainee and the killing of Trayvon Martin, respectively. These are deaths with public and political significance and the poems contribute to and comment upon the public sentiment surrounding them and, in Brady's words, work to 'unsettle our sense of moral priority or certitude.'4

In questioning empathy, I am not alone. Most recently, Paul Bloom's work, culminating in his book Against Empathy: The Case for Rational Compassion, has highlighted how 'empathy is narrow in its focus, rendering it innumerate and subject to bias' because we tend to focus on the individual rather the group, the one child in need rather than the whole suffering community. It can even, he argues, 'motivate cruelty and aggression and lead to burn out and exhaustion', the first because empathy tends to be directed towards the like and the proximate at the expense of others further away or different, and the latter because those who empathise too much render themselves less helpful to others: for instance, the social worker who over-empathises with his clients will be less effective at his job because he is emotionally depleted. ${ }^{5}$ While Bloom accepts that empathy can motivate prosocial behaviour, he warns that it is often used by those who wish to generate animus toward outgroups.' ${ }^{6}$ Bloom's work-and the title of his book-is

4 Andrea Brady and Sarah Howe, 'Interview', Prac Crit 1 (July 2014). Available online: http://www.praccrit.com/poems/song-for-florida-2/. Accessed 24th March 2016.

5 Paul Bloom, 'Empathy and Its Discontents', Trends in Cognitive Science 21:1 (2017), p. 24. See also: Paul Bloom, Against Empathy: The Case for Rational Compassion. New York: HarperCollins, 2016.

6 ibid, p. 27. 
preceded by an article by the philosopher Jesse Prinz, who had made many of the same arguments first. For Prinz, like Bloom, empathy is not 'desirable as a moral emotion' because it clouds our rational judgements. ${ }^{7}$ Instead of compassion, which is what Bloom argues we should cultivate as a better emotion than empathy, Prinz suggests concern, but the reasons both give for not trusting empathy are very similar. ${ }^{8}$ In both arguments, it is not the one who we empathise with who suffers from our empathy, but those who are obscured from view by what Bloom calls empathy's 'spotlight', whereas in the poems I will read it is those empathised with who are displaced by the attempt to imagine them and their situation. ${ }^{9}$

A further problem with empathy is its lack of definitional clarity, resulting in a proliferation of overlapping terms. There is projection (imagining yourself in someone else's place), perspective-taking (imagining what the world looks like from another's position), and cognitive empathy or theory of mind (anticipating how someone else will react); there are distinctions between self-, other- and dual-focused empathy (imagining myself in someone's place, myself as someone else, or imagining both of these). ${ }^{10}$ Often, when empathy is used, imagination is meant. Yet in all contemporary accounts of empathy, whether therapeutic, pedagogic, literary, moral, or psychological, the idea of the other is central. ${ }^{11}$ The most prevalent definitions of empathy stress either the importance

\footnotetext{
7 Jesse Prinz, 'Against Empathy', The Southern Journal of Philosophy, 49 (2011), p. 214.

8 ibid, pp. 230-1.

9 Bloom, p. 25.

10 Definitions of projection, perspective-taking and, to a lesser extent, theory of mind occur often in empathy discussions. See, for instance, the overview in the introduction to Meghan Marie Hammond and Sue J. Kim, eds., Rethinking Empathy Through Literature. New York and London: Routledge, 2014, pp. 7-8. The categories of self-, other- and dual-empathy are drawn from Julinna C. Oxley, The Moral Dimensions of Empathy: Limits and Applications in Ethical Theory and Practice. Basingstoke: Palgrave Macmillan, 2011, p. 26.

11 See for instance, in order: Steve Vincent, Being Empathic: A Companion for Counsellors and Therapists. Oxford: Radcliffe, 2005; Martha Nussbaum, Cultivating Humanity: A Classical Defense of Reform in Liberal Education. Cambridge, Mass., and London: Harvard University Press, 1997, pp. 90-91; Tim Gauthier, 9/11
} 
of imagination in projecting oneself into the position of the other and thus trying to see and feel as they do or, alternatively, the importance of imagining how we would be affected were the same set of circumstances to befall us. ${ }^{12}$ Thus, Suzanne Keen describes empathy as 'I feel what you feel', in contrast to sympathy as only 'a supportive emotion about your feelings', a distinction which is commonly used.13 For others, such as philosopher Julinna Oxley, a more specific set of definitions is required: empathy, she argues, is 'feeling a congruent emotion with another person, in virtue of perceiving her emotion with some mental process such as imitation, simulation, projection, or imagination'. ${ }^{14}$ Tellingly, here, rather than being one of several, imagination is necessary for all the mental processes Oxley lists.

This concentration upon empathy as an activation of imagination explains why literary theorists have been especially drawn to consider empathy in explanations of how readers of narrative relate to characters and their scenarios. Unlike for Bloom and Prinz, literary empathy is usually extolled, whether for the representation of empathy within literary works or the encouragement of a reader's empathy. A focus on how literature imaginatively extends its readers' emotional range and knowledge through encounters with new contexts and experiences is the foundation of Rick Rylance's final chapter on

Fiction, Empathy, and Otherness. Lanham: Lexington Books, 2015; Oxley, The Moral Dimensions of Empathy; Michael C. Corballis, The Recursive Mind: The Origins of Human Language, Thought, and Civilization. Princeton and Oxford: Princeton University Press, 2011. Corballis's text discusses Theory of Mind, an important category in psychology for thinking about how we can imagine and thus predict the reactions of another person.

12 Rajini Srikanth, Constructing the Enemy: Empathy/Antipathy in U.S. Literature and Law. Philadelphia: Temple University Press, 2012, p. 2; Nussbaum, p. 90-1; Oxley, pp. 18-27; Steven Pinker, The Better Angels of Our Nature: The Decline of Violence in History and Its Causes. London and New York: Penguin, 2011. pp. 571-575. Pinker proclaims, 'We live in an age of empathy', p. 571.

13 Suzanne Keen, Empathy and the Novel. Oxford: Oxford University Press, 2007, p. 5. Others make similar distinctions, such as Hammond and Kim, p. 7.

14 Oxley, p. 32. 
empathy in his book-length defence of literature as a public good. ${ }^{15}$ Rylance's argument is germane for what it omits: he does not proffer a definition of empathy-in fact, the word is only used twice in this long final chapter, apart from in the chapter's title, 'The Power of Empathy'. Instead, Rylance concentrates on how literature beneficially exposes readers to new experiences and emotional nuances: in a memorable formulation, he writes, 'In reading literature, we are being “you"'.16 In other literary conceptions, such as those collected in Rethinking Empathy Through Literature, Eleonore de Felip has argued that lyric poetry 'speaking from non-human points of views' can 'help readers to imagine moments of exceptional empathy' with animals, while Mary-Catherine Harrison has argued that the social problem novels of the nineteenth century allowed readers to 'empathize with individual fictional characters' in a manner which introduced them to people 'from social groups who would otherwise be understood as an undifferentiated mass'.17 In the same volume, Eric Leake uses the example of Bret Easton Ellis's protagonist in American Psycho to argue how 'difficult empathy', activated by representations of challengingly unpleasant literary characters with whom 'we might not otherwise wish contact or association', is 'of particular use in novels of critique'.18 In all such accounts, imagining the world differently through reading literature entails empathy.

Most of the theoretical literature on empathy, unless investigating those claimed to lack it, tends to assume that people find it easier to empathise with others who are like

\footnotetext{
15 Rick Rylance, Literature and the Public Good. Oxford: Oxford University Press, 2016, pp. 163-203.

16 ibid, p. 194.

17 Eleonore de Felip, "Hearing the Speechless": Empathy with Animals in Contemporary German Lyric Poetry', p. 102, and Mary-Catherine Harrison, “"The Great Sum of Human Anguish": Statistical Empathy in Victorian Social-Problem Novels', p. 136, in Hammond and Kim.

${ }^{18}$ Eric Leake, 'Humanizing the Inhumane: The Value of Difficult Empathy', p. 184, in Hammond and Kim.
} 
themselves and therefore the more imaginative challenge is cultivating empathy for 'the other who is different'.19 In several accounts, including Rylance's, this is celebrated as a route to developing a richer understanding of people from different cultures and countries. ${ }^{20}$ Yet even this invocation of 'the other who is different' can be problematic if it assumes that there is an identifiable or easily-imagined 'us' against whom that other is measured. The writings of Martha Nussbaum and Tim Gauthier can serve here by way of example: both use 'we' as a convenient placeholder in books that argue for more empathetic relations towards people from different countries to improve cosmopolitanism and combat U.S. insularity. ${ }^{21}$ Neither Nussbaum nor Gauthier believe that North Americans are the sole standard against which all otherness needs to be measured; even so, in such accounts the other is conceived as culturally, nationally, racially or religiously different (or a combination of these factors) to U.S. citizens, who are implicitly bequeathed an inaccurate homogeneity secured by nationality. A keener sense of the diverse ethnicities and cultural heritages that comprise the north American population would arguably be a more advantageous start for those arguing for the importance of imagining otherness. Theorising empathy, it appears, is hard work, full of unimagined pitfalls, but has nevertheless continued to attract theorists and thinkers. Even while the 'we and them' or 'us and others' rhetorical binary upon which empathy frequently rests appears divisive, it is simultaneously the case that empathy, like its far

\footnotetext{
${ }^{19}$ For a discussion of those lacking empathy, see Simon Baron-Cohen, The Science of Evil: On Empathy and the Origins of Cruelty. New York: Basic Books, 2011. Baron-Cohen has worked extensively on autism. 20 See: Nussbaum, Cultivating Humanity; Rylance, Literature and the Public Good; Gauthier, 9/11 Fiction, Empathy, and Otherness; and James Brassett, 'Cosmopolitan Sentiments After 9/11? Trauma and the Politics of Vulnerability', Journal of Critical Globalisation Studies 2 (2010): 12-29.

${ }^{21}$ Albeit a cosmopolitanism firmly anchored in liberal Western values. The use of 'we' is a general feature of Nussbaum's writing style but becomes particularly marked and uncomfortable in discussions of otherness, e.g. 'Narrative art has the power to make us see the lives of the different with more than a casual tourist's interest...', p. 88. Gauthier similarly uses 'we' and 'us' quite frequently, e.g. 'These proposals, on the other hand, use the language of sameness and commonality, emphasizing that a "global event" such as 9/11 should awaken us to our ever-increasing participation within a larger network of communities', p. 1.
} 
older cousin, sympathy, testifies to an impetus towards human connectedness and a recognition of our dependency upon others. Because of this, in the work of Nussbaum and others it has been hailed as a cosmopolitan sentiment in need of further attention and development post-9/11, commended as a key component in effective education for global citizenship, and, as Carolyn Pedwell has identified, been understood as instrumental in political movements calling for greater social justice, including feminism and antiracism..$^{22}$

The list of the benefits to be derived from encouraging an empathetic stance towards others is, despite Bloom and Prinz, predominately laudatory but, as we shall see, it is at a considerable distance from the original sense of empathy brought into English that Lee employed. Lee was keen to distinguish empathy (Einfühlung) from the more usual German sense of the term sich einfühlen, which she translates as 'to feel oneself into something or someone', a definition much closer to how empathy has continued to be understood. ${ }^{23}$ She worries, moreover, that Lipps, whose work her theories of aesthetics built upon, has yielded at points to this common definition and so fallen into 'a little metaphysical mythology'. ${ }^{24}$ The ego cannot project itself into something else, she argues. Instead, it can only understand something else through its experience of itself. Furthermore, in Lee's account, empathy is not felt for others but is an internal reaction (Einfühlung as literally 'in-feeling') to an artwork or object of natural beauty. Her slightly later text, The Beautiful: An Introduction to Psychological Aesthetics (1913), concentrates

\footnotetext{
22 See, respectively, James Brassett, 'Cosmopolitan Sentiments After 9/11?'; Nussbaum, Cultivating Humanity; Carolyn Pedwell, Affective Relations: The Transnational Politics of Empathy. Basingstoke and New York: Palgrave Macmillan, 2014, pp. 46-50.

23 Lee and C. Anstruther-Thomson, p. 54.

24 ibid, p. 55.
} 
on the empathy involved in seeing a mountain rising before us. ${ }^{25}$ Crucial to Lee's conception of how we understand the mountain as rising-even while it is not, of course, growing in size-is that we lift our gaze, even perhaps incline our heads upwards to see it better, so the body moves to match the metaphor. At the same time, in rather tangled prose, Lee explains that 'our awareness of raising or lifting or rising':

...coalesces with the shape we are looking at; in short that the rising continuing to be thought, but no longer to be thought of with reference to ourselves (since we aren't thinking of ourselves), is thought of in reference to what we are thinking about, namely the mountain, or rather the mountain's shape, which is, so to speak, responsible for any thought of rising, since it obliges us to lift, raise or rise ourselves in order to take stock of it. ${ }^{26}$

The observer's psychological and physical reactions 'coalesce' with the mountain's form so it seems to be rising: this is what Lee calls empathy. Moreover, this rising is an accretion of past, present and future risings, both real and imagined, that we have experienced or witnessed:

...and it is this general idea of rising, i.e. of upward movement, which gets transferred to the mountain, along with our own particular present activity of raising some part of us, and which thickens and enriches that poor little thought of a definite raising with the interest, the emotional fullness gathered and stored up in its long manifold existence. ${ }^{27}$

Empathy is coalescence, transference, a simultaneity of action (my eyes rise) and reaction (I attribute this to the mountain) in which verbs of mixing dominate within prose that is performatively muddling.

\footnotetext{
${ }^{25}$ One of the difficulties of glossing Lee on empathy is that her ideas develop and alter with her reading. There is first the essay, 'Beauty and Ugliness', Contemporary Review, October-November, 1897, then the book, Beauty and Ugliness (1912) and The Beautiful (1913), all of which show a progression of ideas.

${ }^{26}$ Vernon Lee, The Beautiful: An Introduction to Psychological Aesthetics. Cambridge: University Press, 1913, p. 63.

27 ibid, p. 65.
} 


\section{Rob Halpern and the Guantánamo Detainee}

It is not surprising, as Caroyln Burdett notes, that reviewers occasionally complained of Lee's convoluted prose, attributable in some instances to her attempts to refute similar concepts in use by other theoreticians. ${ }^{28}$ Notwithstanding, Lee provides a remarkable description of aesthetic responsiveness, and it is a wonder contemporary affect theory has not made her more central to its theorisations, or, indeed, if we attend to the accidental innuendos Lee manages to wring out of rising, why her work is not more used in characterisations of pornography or erotic writing. In turning now to the poetry of Rob Halpern, an unexpected contemporary resonance with Lee's theorisations will become apparent. Halpern's 2015 book Common Place is a complex and disturbingly eroticised elegy for a Guantánamo Bay detainee who committed suicide while incarcerated in 2009.29 The man's autopsy report was subsequently made public, first by the American Civil Liberties Union, under a Freedom of Information request, and later by the international press; this is how Halpern came to read it. The detainee's Guantánamo file has since been published by Wikileaks. ${ }^{30}$ While the U.S. government accused him of fighting for Al-Qaeda, the detainee maintained he only ever fought for the Taliban. He never saw a lawyer in the seven years he was detained at the camp and his death has been seen by some as suspicious or a result of negligence. ${ }^{31}$ In the year before he died he had been on hunger strike and subjected to force-feeding while strapped into a restraint chair. The autopsy, which concludes that he committed suicide using the

\footnotetext{
28 Burdett, p. 1.

${ }^{29}$ Halpern names the detainee in Common Place; here, I shall not in the main body of my text, and the argument that follows will clarify why. However, I do provide references to files which name him.

30 Both documents are still available on the web. The autopsy is one of the many files published on the University of California, Davis's Center for the Study of Human Rights in the Americas Project. See: http://humanrights.ucdavis.edu/projects/the-guantanamo-testimonials-project/testimonies/prisonertestimonies/. The Guantánamo file is available on the Wikileaks website. See: https://wikileaks.org/gitmo/prisoner/78.html. Accessed 25th March 2016.

31 Jeffrey Kaye, 'Recently Released Autopsy Reports Heighten Guantánamo “Suicides” Mystery', Truth Will Out 29 Feb 2012. Accessed 1 June 2016.
} 
elastic from his underwear as a ligature around his neck, mentions that he had made several suicide attempts in the weeks before and was suffering from 'stressors of confinement', noting that lesions on his face were likely the result of banging his head against walls. ${ }^{32}$ The extremity of the conditions under which this detainee suffered and the little we know of him are considerable challenges to attempts to extend towards him or his situation empathy in the contemporary sense of the word. However, as we shall see, Halpern's treatment of the dead detainee has some intriguing and potentially disturbing parallels with Lee's conception of empathy.

Common Place is composed of lyric, prose, and transcription poetry, as well as a kind of poetic essay at the end. Halpern is a skilled writer and his poems are tight and dense, often employing provocative enjambment to keep a restless sense of how contemporary global events have local and personal implications. Common Place can be tender and elegiac, even in a poem entitled 'False Communiqué':

And so I sing this body on a table

For since the war I've read reports i

-magined events studied pro

-cedures assisting incarceration

W/ coroners who must know

Something and whose language

32 ibid. 
Rushes like unfettered streams on

-ly half-knowing the work I mean

Check out this wonder of a guy

A spectacle withdrawn \& covered

With my latinate phrases issue

Displace so gorgeous a figure again ${ }^{33}$

In his determination to pay attention to the dead man, 'this wonder of a guy', 'so gorgeous a figure', Halpern attempts to imaginatively rescue the detainee from the only way the public can know him: through the formal medical prose of his autopsy report. The counter-language Halpern uses to describe this 'guy' is casual, colloquial, and sensually admiring. Yet, if the coroners are deemed complicit in the system that fettered the men they dissect, the language they use is still spoken by the poet, so Halpern renders it 'my latinate phrases' (emphasis mine), aware that he too is reconstructing the dead man. It is unusual for Halpern to use 'this body', with its overtones here of the Eucharist, instead of his more usual appellation 'my detainee', a designation echoing how in his previous book, Music for Porn, he claimed the figure of the dead U.S. soldier also as his. ${ }^{34}$ In both books, the logic of Halpern's imagination is primarily erotic and so in Common Place there are frequent repetitions of how the reading and physical transcription of the autopsy report produce the erectile rising of desire or a set of sexual physiological reactions in the poet-speaker, who is then galvanised into a fantasy that merges and transfers his physical sensations onto the figure of the detainee performing or

33 Rob Halpern, Common Place. New York: Ugly Duckling Presse, 2015, p. 50.

34 ibid, p. 41. 
responding to sexual acts. It is the erotic uses to which Halpern puts the detainee, resurrected into fantasy, that is the most disquieting aspect of Common Place because of its poetic violation of the dead Islamic man. ${ }^{35}$

Before analysing Halpern's imaginative responses to the autopsy report, it is worth considering what the Guantánamo detainee has symbolised in public discourse. As Rajini Srikanth, in her chapter on relations between Guantánamo detainees and their lawyers, describes:

The construction of detainees as "the worst of the worst" and as incapable of suffering (i.e. their suicides are not really evidence of a deep pain but rather are publicity stunts in asymmetric warfare) has precluded the emergence of a publically embraced politics of feeling with regard to their captivity. The detainees are denied subjecthood of any kind-being consigned to the category of potentially lethal weapons. ${ }^{36}$

Srikanth highlights how the public's sympathy requires evidence of suffering, which is not part of the narrative of these men as terrorist enemies of the state and potential suicide bombers. ${ }^{37}$ For Halpern, rather differently, the detainee represents a form of unavowable excess because of his role as a pawn in a larger political and military context:

The detainee's body realises a singularity whose radical specificity arouses precisely what is uncontainable in it: a quality that can't be absorbed by circuits of exchange, a use that may paradoxically be characterised as the embodiment of uselessness under the militarised conditions of our contemporary life world. ${ }^{38}$

\footnotetext{
35 The final section of Common Place, 'Postscript: On Devotional Kink', discusses different objections raised to the poem by friends and people at readings. See also the review by Stephen Boyer in The Poetry Project Newsletter, \#247 (April-May 2016), p. 30.

${ }^{36}$ Srikanth, p. 136.

37 This narrative is starting to shift as more and more detainees are released without charge and then testify to what occurred within Guantánamo. One such account is the remarkable autobiography of a detainee, written from within Guantánamo and published while he was still incarcerated. See: Mohamedou Ould Slahi, Guantánamo Diary. Ed. Larry Siems. Edinburgh and London: Canongate, 2015. Ould Slahi was freed without charge in the autumn of 2016.

${ }^{38}$ Rob Halpern, 'Useless Commodities, Disposable Bodies: An Essay on Value and Waste' in Sam Ladkin, Robert Mackay, and Emile Bojesen, eds., Against Value in the Arts and Education. London: Rowman and Littlefield, 2016, pp. 150-1.
} 
Outside of the law since their containment is extrajudicial, and incarcerated outside of the socius or its sympathies, the detainee's use lies only in his uselessness in confinement. They are kept at the level of 'bare life', in Agamben's philosophical conceptualisation of the term as 'that whose exclusion founds the city of men' but also in a very concrete material sense for the many detainees who have had, for instance, their sole bed sheet confiscated indefinitely, or been shackled naked, or force fed and left in their own faeces. ${ }^{39}$ For Halpern, the body of the detainee 'is what the system must render invisible in order to reproduce the visible'..$^{40}$ Common Place deliberately raisesto invoke a term from Lee-the detainee into imaginative focus.

An example from the section of Common Place entitled 'Funeral Rites' illustrates how Lee's early conception of empathy applies to Halpern's poetry. 'Funeral Rites' gestures to a legacy of gay French writers such as Jean Genet and Pierre Guyotat, whose sexuality spills over into their writing, and to a similar, if more coded, history of American queer erotics discussed by Sam Ladkin as Halpern's 'poetics of masturbation'. ${ }^{41}$ In this scene, Halpern is in the corner of the library, writing: 'my hand around my cock concealed inside the pocket whose lining I've conveniently torn'. ${ }^{42}$ He informs us that 'the glands between my thighs work intensely, generating all the familiar symptoms my Propranolol

\footnotetext{
39 Giorgio Agamben, Homo Sacer: Sovereign Power and Bare Life. Trans. Daniel Heller-Roazen. Standford, C.A.: Sanford University Press, 1998, p. 7. Halpern engages with Agamben's theory in Common Place, p. 149, and in 'Useless Commodities, Disposable Bodies', pp.153-5. The story of the detainee whose bed sheet had been taken away without explanation is told by a lawyer in Srikanth, pp. 150-151. The detainee suspected that his case had caused the removal of his bed sheet, which was making it incredibly uncomfortable at night. He tried to drop his case as a response, causing the lawyer to think 'I'm part of this totally ridiculous worthless system that isn't even worth a bed sheet', p. 151.

${ }^{40}$ Halpern, 'Useless Commodities', p. 153.

${ }^{41}$ Sam Ladkin, "The "Onanism of Poetry": Walt Whitman, Rob Halpern, and the Deconstruction of Masturbation', Angelaki 20:4 (2015), p. 3.

${ }^{42}$ Halpern, Common Place. p. 81.
} 
otherwise subdues, exasperating sweat, swollen tongue \& quickened pulse. Even my perineum feels enlarged.... ${ }^{43} \mathrm{He}$ is transcribing the autopsy report:

But the stylization of his [the detainee's] body's poses creates a series of persistent gestures that animate my form head thrown back like Hecuba mourning on the beach each of which works like a screen to deflect the meanings it appears most to resemble, or a mirror behind which value withdraws, unavailable for use. With torso bent forward, well-built though emaciated, his flesh fills my frame as though a slight change in pressure sucked it all thru an orifice this fault in my syntax whose limit limns a ligature when there's no hope of healing or becoming someone else, a fantasy wherein I raise my head to the level of his knees and in supplication beg for his prick before wiping his forehead so drenched with sweat, the disfigured face relieved by darkness out of which his two black eyes go shining. ${ }^{44}$

The body responds to the work of transcription; words from the autopsy literally 'animate' the poet, exciting him into a sexual fantasy which merges the bodily upheaval of the poet-speaker with the bodily responses (bending forward, sweating) he imagines for the detainee. The object he is responding to-the autopsy report-presents a bodily shape which will not remain inert, and appears to grow until 'his flesh fills my frame', an ambiguous phrase which suggests both a bodily coalescence and penetration. This is not the 'projection of the ego' which Lee decries and which contemporary versions of empathy tend towards when they suggest one imagines what the other is feeling, for the other, in this case, is dead. ${ }^{45}$ And while I am sure that Lee would not deem this as cleanin all senses of the word-an example of what she means by empathy as she provides with her rising mountain, the two constitute provocatively parallel examples of aesthetic and imaginative responses. Halpern's somatic reaction to the autopsy report reanimates the detainee's corpse, violating cultural codes that demand respect for the dead. As the poet's flesh rises, the scene becomes a full-blown sexual fantasy.

\footnotetext{
43 ibid, pp. 80-1.

44 ibid, pp. 81-2.

${ }^{45}$ Lee, The Beautiful, p. 67.
} 
It is thus possible to use Halpern's work here to plot an obscene route through Lee's aesthetics, a use of her work she might have deemed a violation, in fact. Lee insists that empathy 'tends to exist throughout our mental life':46

...entering into what is called imagination, sympathy, and also into that inference from our own inner experience which has shaped our own conceptions of an outer world, and given to the intermittent and heterogeneous sensations received from without the framework of our constant and highly unified inner experience, that is to say, of our own activities and aims. ${ }^{47}$

Halpern's imagination, his inner experience, as well as his own activities are sexual, as far as are communicated in Music for Porn and Common Place. Halpern's desire in pursuing such a necrotic poetry is explained more fully in 'Postscript: Devotional Kink', where, marking out a distinction between his own work and the more computational motivation for much of conceptual writing's electronic copying of source material, he claims:

...I wanted to return transcription to its roots in somatic practice, to bring my body into contact with the linguistic remains of extraordinary rendition and state-sponsored death, like a scribe reproducing Torah or a monk labouring over illuminated books unable to restrain himself from spilling into the text. How would my writing prosthetic of nerve \& bone metabolize such language in an effort to perceive my body's relation to a detainee's occulted corpse? ${ }^{48}$

Halpern's relation to the corpse is sexual, prompted by the autopsy's focus on the body. Lee's experiments with aesthetic empathy also had a queer dimension: for years, her and her partner, Clementina (Kit) Anstruther-Thomson, looked at artworks together and recorded their reactions, testing out various hypotheses and relating their results to the continental theories of aesthetics and psychology they were reading. Anstruther-

\footnotetext{
46 ibid, p. 68.

47 Ibid, p. 68.

${ }^{48}$ Halpern, Common Place, p. 155. The final question here is repeated in 'Useless Commodities', p. 151.
} 
Thomson's body was more receptive than Lee's own, she eventually concluded, and had therefore been the focus of their investigations, a fact read by some later commentators as a form of sublimated desire. ${ }^{49}$ Even in contemporary understandings of empathy, mostly quiet on matters erotic, there is at least one theorist who comments that empathy can be sexual. ${ }^{50}$ It makes sense that Halpern's poetry brings out the untheorized queer implications in Lee's conception of empathy.

Halpern refuses to 'presume to recognize [the detainee's] suffering': Common Place deliberately does not try to imagine it. ${ }^{51} \mathrm{He}$ declares that in this situation 'there can be no compassionate identification with the other'. ${ }^{52}$ This cauterises the potential for empathy in its contemporary sense, too, since empathy, compassion, and identification all require an engagement with the other that responds to their context. The poems of Common Place refuse to imagine the detainee as the detainee, raising him instead into a sexual fantasy, in what Halpern calls 'the reinvention of use' but which can also be read as a violation. ${ }^{53}$ Halpern's refusals of empathy and imagination are the ethical stakes of Common Place. Thus Lee's empathy is the only kind of empathy we can identify in the poetry. Halpern recognises the sexual scandal of his poems and knows they might be read as violations, admitting that 'to sexualize exploit the body of a hunger-striking detainee crosses a line...to make the body of the detainee's body the common place of my devotional kink is like ripping a hole in his corpse in order to go on fucking it.'54 The grisly simile he reaches for unapologetically consolidates that violation.

\footnotetext{
49 For a discussion of Lee's formulation of empathy and its queer beginnings, see Burdett, pp. 12-13.

50 Keen, p. 40.

51 Halpern, Common Place, p. 162.

52 Halpern, 'Useless Commodities', p. 155.

53 Halpern, 'Useless Commodities, Disposable Bodies', p. 156.

54 ibid, p. 160.
} 
Halpern's poems search for the basis of a new form of community by confronting what is currently excluded. But, as fellow poet Andrea Brady has recently argued in a lengthy discussion of Common Place, this 'instrumentalisation of the body' of the detainee, 'is not unlike capitalism in forcing the "disposable body" to work, to create the surplus value which is its theory of the commons' ${ }^{55}$ This rapaciousness is a sexual violation of the memory of a man whose religion, Islam, forbids same-sex relations, as Brady also notes, and is the reason why I have withheld his name from this article. ${ }^{56}$ Imaginative, transgressive, and in many ways, ethically complex and committed as Halpern's Common Place is, it fails to imagine how the detainee's family might feel about the sexual use to which his corpse is put, and fails to imagine that the detainee, before his death, would have likely have interpreted such a use as yet another U.S. violation committed against him. In being against empathy as we know it today, yet through that embodying Lee's conception of empathy instead, the very problem Common Place performs is its imaginative recursivity: it cannot get beyond the self of the poet, and the poet's desire is violating, as Halpern acknowledges.

\section{Andrea Brady and Trayvon Martin}

Halpern and Brady are poets committed to confronting the political and its uncomfortable ramifications. My second example of a poem that points to the limitations of contemporary understandings of empathy is Brady's 'Song for Florida 2', about the shooting of unarmed black teenager Trayvon Martin in Sanford, Florida in 2012 and the subsequent trial and acquittal of his killer, George Zimmerman. From its outset, this work

\footnotetext{
55 Andrea Brady, 'Poetry and Bondage: Halpern to Wyatt', talk delivered at New York University on 1 April 216 and Yale University 4 April 2016, p. 44. My thanks to Andrea Brady for sharing this unpublished essay with me. 56 ibid, p. 43.
} 
responds to violations of justice: first, Martin's shooting, and then the lack of conviction for his killer. Brady's poem incorporates facts and found material from the trial and its reporting, including quotes from Zimmerman's much-discussed call to 911. The poem is a condemnation of racial bias and violence in the United States' population and justice system and, in Brady's words, 'a kind of elegy' for Martin. ${ }^{57}$ In the final third of the poem, Brady explores what she calls, in an accompanying interview, 'the possibility of sympathising with Trayvon Martin's parents' experience-the possibility or impossibility of that empathetic identification'. ${ }^{58}$ Brady's resultant exploration of how empathy might violate is considerably more nuanced than the violations of Common Place. In the interview, she employs sympathy and empathy as loose synonyms together with identification, which, despite its complex psychoanalytic connotations, is used here with 'empathetic' in a more colloquial sense that addresses the reactions to Martin's death. In the immediate aftermath of Zimmerman's acquittal, people across the U.S. took to the streets, and social media sites were flooded with images of black people holding hand-made signs proclaiming 'I am Trayvon Martin'. Criticisms and denunciations of the court's ruling were accompanied with the hashtag \#BlackLivesMatter, popularised by Patrisse Cullors, Opal Tomesti, and Alicia Garza, who now lead what has mushroomed into an international organisation. ${ }^{59}$ Martin, who was wearing a hoodie at the time he was shot, was described by Zimmerman in his call to the police as black and 'a real suspicious guy' who 'looks like he is up to no good, or on drugs or something' because '[i]t is raining

\footnotetext{
57 Brady and Howe. See the following two collections of essays for work on how policing, the courts, and the general population are racially biased in the United States: Devon Johnson, Patricia Y. Warren and Amy Farrell, eds., Deadly Injustice: Trayvon Martin, Race, and the Criminal Justice System. New York and London: New York University Press, 2015; George Yancy and Janine Jones, eds., Pursuing Trayvon Martin: Historical Contexts and Contemporary Manifestations of Racial Dynamics. Lanham: Lexington Books, 2013.

58 ibid.

59 Within 26 hours of the verdict, 4.9 million tweets had disseminated this information. These were predominantly without comment, but a notable 31\% expressed opposition and only 7\% support. See: Chenelle A. Jones and Mia Ortiz, 'The Zimmerman Verdict: Media, Political Reaction, and Public Response in the Age of Social Networking' in Johnson, Warren and Farrell, pp. 275-297.
} 
and he is just walking around, looking about'.60 The 'I am Trayvon Martin' signs and the Tumblr created in his name, inviting people to send in photographs of themselves 'looking suspicious' in hoodies, underline the racist assumptions that immediately deem young black men suspicious and dangerous even when involved in everyday activities, as Martin was in popping to the shop to buy candy. ${ }^{61}$ It is to the outpouring of identification with Martin that Brady is referring in the interview.

While the urge to identify with Martin through a shared black vulnerability to white violence is understandable and undoubtedly political, there are theorists who are wary of political solidarities built in such ways or based upon empathy between those who have been hurt and traumatised. The two strongest arguments made in this vein are put forward by Lauren Berlant and Wendy Brown and concern particularly what they call respectively 'subaltern pain' and 'politicized identity'.62 Berlant's argument, put simply, is that solidarity built through empathising with the pain of oppression does not, ipso facto, make for an effective political imaginary for structural change. Berlant fears a politics founded in feeling not because injustice is not real or fails to pain its victims, but because those feelings do not necessarily tell us what a just world or a more just conception of the good life might look like. ${ }^{63}$ Brown's complementary point, although it does not directly condemn empathy, analyses how political opposition originating from oppressed minorities tends to measure injustice as unequal treatment before the law,

60 The transcript was published online by the news website, Mother Jones. See: http://www.motherjones.com/documents/326700-full-transcript-zimmerman. Accessed 26 May 2016.

61 For a discussion of how black men are rendered invisible as individual citizens but highly visible as a dangerous group, see Jacqueline Anderson, Sarah Lucia Hoagland, and Anne Leighton, 'Now You See It, Now You Don't: Magic Tricks of White Supremacy in the United States' in Yancy and Jones, pp. 25-32.

${ }^{62}$ Lauren Berlant 'The Subject of True Feeling: Pain, Privacy, and Politics' in Wendy Brown and Janet Halley, eds., Left Legalism / Left Critique. Durham and London: Duke University Press, 2002, p. 122 and Wendy Brown, States of Injury: Power and Freedom in Late Modernity. Princeton, N.J.: Princeton University Press, 1995, p. 54.

63 ibid, p. 128. 
which implicitly agitates to be included within a system built around the privileges of a white liberalism instead of 'conjuring an imagined future of power to make itself'. ${ }^{64}$ In these critiques, empathy, or what Brady calls 'empathetic identification', foreshortens capacities for imagining an alternative future by tethering people too closely to their traumas and wounded sensibilities. Additionally, Berlant is justifiably wary of understanding the social world as an affective space where people ought to be legitimated because they have feelings' ${ }^{65}$ It is easy to see an injustice was committed in the Zimmerman case and reasonable for anger to be the response, but that does not necessarily mean that the perception of injustice and the anger that follows it are always and in all cases justified; and nor is a beneficent and other-inclusive emotion, as empathy is supposed to be, sufficient as the foundation for an ethical politics, as Bloom and Prinz would no doubt agree. ${ }^{66}$

An alternative stance, one which also abandons empathy and the site of specific trauma as political unifiers but seeks instead a more generalised and factual shared similarity, is offered by Judith Butler in her book Precarious Life. She suggests we experience a 'primal vulnerability', initially as dependent infants exposed to others, their care, and perhaps their violence. ${ }^{67}$ Butler asks us to imagine a community wherein 'we are alike only in having this condition [of vulnerability] separately and so hav[e] in common a condition that cannot be thought without difference'.68 Vulnerability is common to us all, but

\footnotetext{
64 Op. cit., p. 66.

${ }^{65}$ Lauren Berlant, The Female Complaint: The Unfinished Business of Sentimentality in American Culture. Durham and London: Duke University Press, 2008, p. 2.

${ }^{66}$ For a discussion of anger and justice, see: Philip Fisher, The Vehement Passions. Princeton and Oxford: Princeton University Press, 2002.

${ }^{67}$ Judith Butler, Precarious Life: The Powers of Mourning and Violence. London and New York: Verso Books, 2004, p. 31.

68 Ibid, p. 27.
} 
different for each according to their context and circumstance. Butler advocates nurturing our acknowledgement of this vulnerability in both ourselves and others, especially in the wake of $9 / 11$, a time period which 'offers a chance to start to imagine a world in which that violence might be minimized, in which an inevitable interdependency becomes acknowledged as the basis for global political community'. ${ }^{69}$ Precarious Life is part of the 'process of that imagining', she hopes. ${ }^{70}$ As with Berlant and Brown, for Butler imagination creates new political ways of being in the world. However, it is not empathy that we need to appreciate another's vulnerability, but, in line with the trajectory of Butler's work, a reconfigured Hegelian recognition of difference. Empathy and vulnerability may sound the same, since both bridge differences and reach towards understanding similarities between people, but they are not. Vulnerability, for Butler, is a constitutive state of being human, whereas empathy is an emotion not everyone experiences. $^{71}$

The 'I am Trayvon Martin' signs recognise black vulnerability to racist misinterpretation by whites and the potentially life-threatening consequences. ${ }^{72}$ As protesters and critics of the verdict pointed out, Zimmerman's descriptions of Martin were heavy with the stereotyping of young black men as urban delinquents, which, in the words of Cathy J. Cohen, is 'yet another trope that [has] helped to create and solidify an "other" that whites

\footnotetext{
69 ibid, p. xii-xiii.

70 ibid, p. xiii.

71 Baron Cohen, The Science of Evil. Harrison also discusses the phenomenon of statistical empathy, whereby the greater the numbers of people involved in a tragedy the harder it is for people to empathise in Hammond and Kim, pp. 135-149.

72 Zimmerman's killing of Martin has generally been seen as an act of white racist violence. However, Zimmerman's mother is Peruvian and his father of German ancestry so he is mixed-race Hispanic or what has been referred to by some as 'white Hispanic'. See Nicole Akoukou Thompson, 'George Zimmerman's Ethnicity: Is He White, Latino, or “White Hispanic”?', Latin Post, 24 October 2013.

Available at: http://www.latinpost.com/articles/3250/20131024/george-zimmerman-ethnicity-whitelatino-hispanic.htm. Accessed 21 May 2016.
} 
and middle-class people of color could rally against', contributing to an atmosphere of 'white fear'. ${ }^{73}$ White fear is thus a perception of white vulnerability to black violence that in fact makes most vulnerable the black people who are feared. The stakes in whose vulnerability is recognised as legitimate are high, and sometimes, as in Martin's case, fatally unjust. Butler argues that the recognition of another's vulnerability is a performative act, changing the nature of that vulnerability, and it is this that the 'I am Trayvon Martin' signs hope to achieve in highlighting a shared vulnerability to racism. ${ }^{74}$

Brady's poem marks white fear and black vulnerability from the start:

You may be called upon

to testify to your worst fears

it was a dark and rainy

(setting the scene)

was dark and

(set)

and mangling the apparition can't be

gated, dog whistles, blocks

these assholes always get the specter of

the elevator, shadow of

grass and graven recess down

ever-hooded sea. ${ }^{75}$

${ }^{73}$ Cathy J. Cohen, 'Afterword: When Will Black Lives Matter? Neoliberalism, Democracy, and the Queering of American Activism in the Post-Obama Era' in Travis L. Gosa and Erik Nielson, eds., The Hip Hop and Obama Reader. New York and Oxford: Oxford University Press, 2015, p. 282.

74 ibid, p. 43.

75 Andrea Brady, 'Song for Florida 2', Prac Crit 1 (July 2014). Available online: http://www.praccrit.com/poems/song-for-florida-2/. Accessed 24th March 2016. All references refer to this online page and so I will not give further footnotes for the poem. 
The worst white fears, of dark and shadowy, hooded 'assholes' threatening their gated communities like apparitions or spectres, mix here in a halting, fragmentary manner with extracts from Zimmerman's 911 call after he saw Martin in his neighbourhood. ${ }^{76}$ Much of the case hinged upon Zimmerman's memory, his interpretation of the scene and of the young man Martin. In the poem, 'Dark' first refers to the weather conditions of that night, but echoes the pathetic fallacy in setting the scene for what will come. The next iteration, 'was dark and', leaves an unspoken indent where Martin's name could go, had he not been killed, or had Zimmerman admitted that the teen's skin colour had inspired the conclusion that he was suspicious. Finishing on 'and' the line suggests that skin colour has ramifications which might be 'set' insofar as there is little that can be done to alter pre-determined negative views.

While they initially sound like references to elements of a neighbourhood, 'gated, dog whistles, blocks' can all be read as manifestations of racism: the gated communities that protect rich whites from the poor, often black communities they keep out; the political 'dog whistle' is a racist slur readable only to those who catch its undertones; 'blocks' compounds the containment and restraint carried by the three previous words, adding the physical sense of stoppage embodied in the Stand Your Ground laws in Florida and running on into the next line, which is from Zimmerman. ${ }^{77}$ 'These assholes they always get away', he said in the police call, but Brady here replaces the final word, for Martin did

\footnotetext{
76 Zimmerman had a history of calling the police about such matters and often about black men. See http://www.motherjones.com/documents/327330-george-zimmerrman-911-call-history. Accessed 24th March 2016. Recently, his vulgar auctioning of the gun which killed Martin for $\$ 250,000$ and his statement that some of proceeds would serve to 'fight [Black Lives Matter] violence against law enforcement officers' makes clear he assumes black people are a threat to law and order. See: 'Gun that Killed Trayvon Martin "Makes $\$ 250,000$ for Zimmerman"', $B B C$ News, $22^{\text {nd }}$ May 2016. Available at: http://www.bbc.co.uk/news/world-us-canada-36354206. Accessed 23rd May 2016.

77 For an exploration of this last point, see: Devonya N. Havis, "Seeing Black" through Michel Foucault's Eyes: "Stand Your Ground" Laws as an Anchorage Point for State-Sponsored Racism' in Yancy and Jones, pp. 117-228.
} 
not get away; instead, he got the spectre of white fear in fatal form. In Brady's poem, Zimmerman's regurgitated words indict him in a manner they did not manage to achieve in court. 'Song for Florida 2' opens by intimating that we are all implicated in this scenewith its opening addressing to 'you'-and the final line quoted above, repurposed from Wallace's Stevens' 'The Idea of Order at Key West', is the start of the poem's engagement with what Brady calls, in interview, his 'chiaroscuro poetics, and its divisive visual imagery' which repeatedly pits whiteness against blackness or darkness. ${ }^{78}$ The fact that racism is embedded within language, in poetry as much as in calls to the police, is one of 'Song for Florida 2"s most implacably made points.

It is in the third and final section of the poem that Brady begins to experiment with what she has called 'empathetic identification'. The poem returns to the scene of death, firstly through Zimmerman's words from the 911 tape, then by tenderly describing Martin's dead body on the grass, and finally by failing to fully imagine the death of Brady's own son. Remarkable in this section is the address to Martin himself:

I can be your mother, your friend, your victim, your juror I can't be you I can't be so quickly and inevitably dead

The poet cycles through the positions of people affected or involved in Martin's death and the trial, a classic example of perspective-taking, as the language of empathy might class it, but treated too swiftly to be convincing. What looks like empathy can be dispensed fast from the position of white privilege. Yet, these lines can also be read as venturing a disquieting displacement of the black people who cared deeply for the teen, Martin's own mother and his friend, Rachel Jeantel, whose diction during her trial evidence was

\footnotetext{
78 ibid.
} 
commented upon unfavourably in certain news reports. ${ }^{79}$ The violating effect of this usurpation is amplified by including in the list the women who failed to convict Zimmerman, and even the suggestion that Zimmerman is Martin's victim, a potential that the poem has not until now countenanced. This kaleidoscopic position-taking, levelling all the participants to interchangeable parts of an imaginative thought experiment that ends in death, indicts empathy as empty, a form which looks good on the surface but lacks moral content and thus leads to violation.

Instead of dwelling here, though, the poem attends to the scene of death, noting, 'That is the cross of your ankles / they are tender to each other and to the hands that washed them'. But Brady quickly pulls herself out of imagining this scene, admitting, 'That is not my son. It is someone else's. / I perjure myself'. Here is a further violation, a further cuckoo intrusion into the other's family. Is Brady imagining herself as Martin's mother or imagining that Martin is her son? It could be either, and the poem marks these violations as the ethical limit to imagination, beyond which would be a transgression into bearing false witness. Empathy is shown to end in falsehood here, even in a kind of child appropriation, until the poet refuses to continue. Empathetic identification, Brady intimates, can be almost seductive, drawing the empathiser into gestures that over-step propriety. There is another option, in the lexicon of empathy's positions, however, and Brady exhausts it in the poem's final few lines by attempting and failing to imagine the death of her own son, in the place of Sybrina Fulton's:

...my son unhoods himself

for the summer his hair is white

his head is so dear and so expansively loved

\footnotetext{
${ }^{79}$ For an article which summarises these criticisms, see: Jelani Cobb, 'Rachel Jeantel On Trial', The New Yorker (27 June 2013). Available at: http://www.newyorker.com/news/news-desk/rachel-jeantel-ontrial. Accessed: 8 April 2016.
} 
then he flashes invisibly and safely

into the grass we own.

Oh Florida, protect his dear head forever

from the likes of $Y O U$ I kiss him into life

I go with the majority if the majority

never bleeds I have to hold out

my hand to catch his blood if I'm

to get any

Brady's son's safety is emphasised in the clarity of the lyrical lines dedicated to describing him: unlike Martin, he is invisibly white, unhooded, and safely surrounded by his parents' private property. While Florida-and by implication, its Stand Your Ground exemptions and their racist implementation in the law-is condemned directly, with the famous Uncle Sam capitalised interpolation, the poet too indicts herself, in going with the majority. The last four lines of the poem are complex, bracketed with two conditionals that double-layer the imaginative contingencies at stake. 'I go with the majority if the majority' goes against the principles of majority rulings, which structure both democracy and justice in the U.S.A., since it suggests that one can impose conditions on a situation which does not allow for them. In the U.S.A., as the poem has repeatedly explored, the majority is white and potentially racist, so the line's run-on syntax suggests the poet plays it safe, going with the majority if it precludes pain and death. '[I]f the majority / never bleeds' seeps into the necessity of reaching for the blood of the son who does. In the final conditional, blood can only be caught-stopped?-through a supplicatory hand, that universal gesture to ask for aid.

In the poem, Brady's son does bleed, though not necessarily to death. Imagining the death of one's child Brady deems a kind of violation in itself, calling it, in the interview, 'the 
black hole of thought', and thereby reproducing the same linguistic error for which she upbraids Stevens. ${ }^{80}$ In the poem, the bleeding son-hers, but also, of course, Martinleaves the poet potentially with blood on her hands. Brady is implicated in the racism that killed Martin, not just because she is American and alludes to memories of childhood racism in the poem, but precisely because her white son is safe while a black son dies at the hands of a racist. Brady does not quite put herself in Fulton's position or imagine for her own son the fate that befell Martin. That would be the violation the poem wants to mark as the imaginative limit. Such a violation might fulfil the demands of empathy but would miss the intersectional point: Brady's white son is highly unlikely to have been treated in the same way by Zimmerman and the poem's reluctance to empathise underlines how the dynamics of race, class, and nationality dictate our lives and life chances. The ethics of such an imaginative refusal of empathy lie in recognising the differences between people caused by their structural positions in a socio-economic order that is still disastrously racist, misogynistic, and economically uneven and unjust.

In Beauty and Ugliness, Vernon Lee upbraids Theodor Lipps for 'the dangerous advantage of using an already existing expression for a new idea' in his coining of Einfühlung, which became empathy. ${ }^{81}$ We can only wonder today what might be the name for trying to imagine another's situation or how circumstances look from their perspective if Lee and others interested in psychological aesthetics had not brought empathy into English. As it is, empathy is repeatedly subdivided and redefined in the critical, philosophical, and psychological literature. In Halpern's Common Place, Lee's original conception of empathy as an aesthetic affect is evident and leads to violation. The poems lack empathy

\footnotetext{
${ }^{80}$ Howe and Brady.

${ }^{81}$ Lee and C. Anstruther-Thomson, p. 46.
} 
in its contemporary sense because Halpern deliberately refuses what he sees as an impossibility. Within this poetics, any attempt to empathise with the detainee would be a violation, even while the alternative violates the dead man's religion. In Brady's 'Song for Florida 2' empathy is show to be an inadequate concept: putting ourselves in the place of the other supplants and erases them and their grief; and imagining what we might feel if their fate belonged to us or our beloveds results in the erasure of the differences which make the other's world unlike our own, when we need instead to acknowledge the injustices of those differences. These poetic works on political deaths echo the distrust of Bloom, Prinz and Berlant for empathy, which proves to be not simply an insufficient concept for imagining how to build a more just world but, through the imaginative violations it can entice us to, a dangerous way of obliterating the differences to which we need to urgently attend for that imagining to take place. 